influx into alveoli and ultrastructural differentiation. Pediat. Res.. 11:197 $(1977)$.

33. Zeligrs, B. J.. Nerurkar. I.. S., and Bellanti. J. A.: Increase in fungicidal activity of rabhit alveolar macrophages during animal development. (In preparation.)

3. This research was supported hy National Institutes of Health (irant HI.

Copyright $\sqrt{ } 1977$ International Pediatric Research Foundation. Inc
$167+8$

5. Reyuest for reprints should be addressed to: Barhara J. Zeligs, Department of Pediatrice Room 30 Gorman Bldg. (ieorgetown University School of Medicine, 3800 Reservoir Road. N.W.. Washington. D.( . 20007 (USA) 36. Received for publication February 22, 1977

37. Accepted for publication March 30.1977.

Printed in U.S.A.

Pediat. Res. 11: 1211-1214(1977)

Diphtheria

IgG subclasses restricted antibodies tetanus

\title{
Partially Restricted Antitoxins of Tetanus and Diphtheria in Man
}

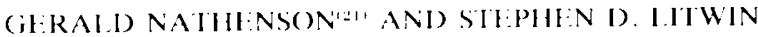 \\ Department of Pediatrics. Montefione Hospital and Medical Center and the Albert Einstein Colle'ge' of Medicine. \\ Bromx, and Department of Medicine (Cienetics). New York Hospital, and the Cornell Medical College. New \\ York, New York. LSA
}

\begin{abstract}
Summary
Antibodies of restricted specificity have been identified in the human in response to certain antigens. The present study analyzed tetanus and diphtheria antitoxins isolated from selected human sera and suggested a restricted reponse in antibody production to each of these antigens. Purified antibodies from eight serum specimens with elevated hemagglutination titers to tetanus and four to diphtheria yielded only $\lg G$ proteins in concentrations of $160-500 \mu \mathrm{g} / \mathrm{ml}$. Although some of the tetanus specimens were derived from cord sera and tetanus immunoglobulin, none of the total group had antibodies of the $\lg A$ and IgM classes. Utilizing immunoelectrophoresis against heavy chain subclasses, genetic markers, and $\kappa$ and $\lambda$ quantitations, a predeliction for the $\kappa \operatorname{IgG} G_{1}$ subclass was established for both tetanus and diphtheria antibodies. The $\lambda$ light chains were present in diminished quantities, IgG, heavy chains were absent. and the $\operatorname{IgG} G_{3}$ and $\operatorname{IgG}_{4}$ chains were variably identified.
\end{abstract}

\section{Speculation}

The elucidation of those antigens which result in restricted antibody formation has apparent clinical significance, in view of the fact that some individuals possess selective defects in the production of certain $\lg G$ subclasses.

The light and heaty chain differences cause human immunoglobulins of each of the classes to exist in several forms. in accordance with variations in the way in which these chains combine. Since $\lg (j$ heavy chains. ats an example. occur in four subclasses ( $\lg \left(j_{1}, \lg \left(j_{2}, \lg G_{3}\right.\right.$. and $\operatorname{Ig}\left(j_{4}\right)$ and the light chains in two types $(\kappa$ and $\lambda)$. eight different $\lg (\mathrm{i}$ molecules are possible by varving combinations of light and heavy chains. Normally, the Ig( $i_{1}$ subclass constitutes about of ${ }^{2}$ of total $\lg (i, 23 \%$ $\lg \left(i_{2} .7 \% \lg \left(i_{3,}\right.\right.$, and $f^{\prime \prime} ; \lg \left(i_{1}\right.$. When combined with the $\lg \left(i_{1}\right.$ chain. the light chain $\kappa: \lambda$ ratio is about $2: 1$

Although most antibodies produced in the human appear to be heterogencous. the response to certain antigens may result in antibody immunoglobulin which is relatively or even completely restricted. Rh antibody, as an example, is primarily an $\lg G_{1}$ immunoglobulin with some $\lg B_{3}$ and $\lg \left(_{4}\right.$ but no $\lg i_{\text {. }}$ molecules (5. 10). whereas bacterial polssacharide antigens elicit predominantly $\lg { }_{3.2}$ production (7). Antibodies against factor V'Ill are formed preferentially within the $\lg \mathrm{G}_{1}$ subclass (1). Levan prowetes a highly restricted manufacture of $\kappa \operatorname{lgG}_{2}$ globulins. approaching the homogeneity of a myeloma protein (17).

Utidizing available immunologic techniques, criteria have been proposed for establishing antibody specificity (3. 16). Employing several of these criteria, the results of this investigation suggest that the human responds with partial antibody restriction to the toxins of ('ostridium tetani and Corrnebacterium diphthe' ria.

\section{MATHRIALS ANI MFTHODS}

light specimens containing tetanus antibodies were derived from three sources: five were samples of newborn cord sera. two were taken from human antitetanus immunoglobulin pools. and one wats serum of a s-year-old burn patient taken several wecks after a tetanus toxorid booster immunization. Four sera containing diphtheria antibodies were from children, aged 7 months to 11 years, with recent clincal diphtheria. Specimens were obtained within a period not exceeding 6 months from the time of active disease. Antibedy titers to tetanus and diphtheria in serat and in purified antibody preparations were measured by a hemagglutination technique using the toxoids of either antigen coupled to human type o Rh' red blood cells by the chromic chloride method (2).

Purified antibody preparations were prepared in the following manner. Tetanus or diphtheria toxoid (Wyeth. aluminum-precipitated toxoid containing $0.01 \mathrm{mg}$ protein $\mathrm{N} / \mathrm{ml}$ for tetanus and $0.0(1)$ mg protein $\mathrm{N} / \mathrm{ml}$ for diphtheria) $(3-4 \mathrm{ml})$ was incubated with $1 \mathrm{ml}$ serum for 1 hr at $37^{\circ}$. then refrigerated wernight. The precipitate was washed 12 times. The supernatant and carly washes were discarded after being tested for specific antibedy activity. The precipitate was then incubated with acid-glycinc buffer. pH $3.0(1 \mathrm{ml})$. overnight at $\mathrm{rocm}$ temperature. The supernatant was dialyed against normal saline for $1 \mathrm{hr}$ and the residual material discarded. The diatysate (about $1 \mathrm{ml}$ in quantity). representing a purified antibody preparation. Was used for subsequent analyses. 
The following methods were applied to sera or the purified preparations to establish the nature of the antibody isolated. (1) The major immunoglobulin classes were quantitated by double radial immunodiffusion using commercially available reagents (6). (2) $\mathrm{Gm}$ (a). Gm (b). and $\mathrm{Gm}$ (f) antigens (Gm numerical nomenclature: $\operatorname{Gm}(\mathrm{a})=1 ; \mathrm{Gm}(\mathrm{b})=5 ; \mathrm{Gm}(\mathrm{f})=$ 4) were typed by inhibition of hemagglutination using specific Gm antibodies and appropriate Rh coats of known $\mathrm{Gm}$ specificity. coupled to Rh positive red blood cells (13). The Gm (a) and $\mathrm{Gm}(\mathrm{f})$ markers were used to identify the $\operatorname{IgG}_{1}$ heavy chain and the $\mathrm{Gm}(\mathrm{b})$ marker, the $\lg \mathrm{G}_{3}$ heavy chain. $\mathrm{Gm}(\mathrm{a})$ and (f) quantitations were done by an automated method. described by Litwin $(t)$. which measures the percentage of inhibition of hemagglutination of each Gm type. (3) The $\kappa$ and $\lambda$ light chains were quantitated by double radial immunodiffusion on plates prepared in our laboratory using specific antisera derived from immunization of New Zealand white rabbits with isolated BenceJones proteins. (f) The heavy chain subclasses of $\operatorname{Ig} G_{1}, \lg G_{2}$. $\mathrm{IgG}_{33}$, and $\mathrm{IgG}_{4}$ were identified by immunoelectrophoresis and double diffusion against specific heavy chain antisera obtained from immunization of New Zealand white rabbits with specific mycloma proteins having $\operatorname{Ig} G_{1} . \operatorname{Ig}_{2}$. and $\lg _{4}$ chains. $\operatorname{Ig} G_{33}$ antisera was obtained by immunization of a baboon with an $\mathrm{IgG}_{3}$ mycloma protein.

\section{RESULTS}

The major serum immunoglobulin classes in patients $G$ (tetanus) and 39,40 , and 1.31 (diphtheria) were within normal limits, with mean values of $\operatorname{lgG} 1194 \mathrm{mg} / \mathrm{dl}, \operatorname{lgM} 117 \mathrm{mg} / \mathrm{dl}$. and $\lg \mathrm{A} 2.39 \mathrm{mg} / \mathrm{dl}$.

The titer of purified tetanus antibody. with one exception. was one to three 2-fold tube dilutions lower than that found in the sera. Of the major immunoglobulin classes. $\operatorname{Ig} G$ was present. and $\operatorname{Ig} M$ and $\operatorname{IgA}$ were absent in all separations (Table 1). The lowest limit of sensitivity for the detection of $\operatorname{IgA}$ and $\operatorname{IgM}$ was $5 \mu \mathrm{g} / \mathrm{ml}$. The same information for the purified diphtheria antibody preparations is shown at the bottom of Table 1 . Here, the antibody titers were all one 2-fold tube dilution lower than the levels in serum. As noted in the cetamus preparations. purified diphtheria antibody revealed the presence of $\lg G \gamma$ globulin only. IgM and $\operatorname{IgA}$ were absent.

Table 2 shows the $\kappa$ and $\lambda$ light chain quantitations. and the corresponding $\operatorname{IgG}$ concentrations of the purified tetanus antibody preparations. Both $\kappa$ and $\lambda$ light chains were identified; the proportion of $\operatorname{Ig} G$ molecules containing $\kappa$ chains was 8()$-$ $90 \%$ of the total. as compared to $10-20 \%$ for the $\lambda$. The lower limit of sensitivity for the detection of lambda molecules was about $25 \mu \mathrm{g} / \mathrm{ml}$. The data for purified diphtheria antibody shou similar proportions of $\kappa$ - to $\lambda$-containing antibody.

The heavy chain analyses of tetanus purified antibody. as determined by the $\mathrm{Gm}$ systems which identify $\lg \mathrm{G}_{1}$ and $\operatorname{Ig} \mathrm{G}_{3}$. and by immunoelectrophoresis with specific subclass antisera for all four types. are depicted in Table 3. For comparison. Gm phenotypes of the sera are also shown with each corresponding phenotype of purified antibody in the adjacent column. Fach of the samples reveal $\mathrm{Gm}$ (a) and/or $\mathrm{Gm}$ (f) markers and. as expected. the $\lg \left({ }_{1}\right.$, heavy chain on which these antigens are located is present. Where $\operatorname{Gm}(b)$ is found. so also is the $\operatorname{Ig} \mathrm{z}_{33}$ chain. The $\lg G_{2}$ and $\lg G_{4}$ heary chatin identification. shown by antisera reactions only. reveal the absence of $\lg G_{2}$ chains in ail of the specimens (with the exception of $T I G / I I /$, which was not tested).

Data for diphtheria purified antibody are shown in Table 3. The $\mathrm{Gm}$ and heavy chain antisera analyses correspond. In each of the four specimens $\operatorname{Ig}\left(j_{1}\right.$ and $\operatorname{Ig} G_{4}$ heary chains are present and $\lg \mathrm{B}_{2,2}$ and $\lg \mathrm{G}_{3}$ chains are lacking. The lower limit of sensitivity for the detection of heavy chatins $w a t s=15 \mu \mathrm{g} / \mathrm{ml}$.

The $\mathrm{Gm}(\mathrm{a})$ and $\mathrm{Gm}(\mathrm{f})$ allotypic quantitations, as a reflection of the amount of $\lg \left(i_{1}\right.$ heavy chain present in the purified specimens. are shown in Table 4 . Determinations were made
Table 1. Purified antibody preparations (immunoglobulin classes (micrograms per ml))

\begin{tabular}{|c|c|c|c|}
\hline Paticnt & $\lg (3$ & $\operatorname{IgM}$ & $\lg A$ \\
\hline \multicolumn{4}{|l|}{ Tetanus } \\
\hline$B t^{\prime}$ & 500 & 0 & 0 \\
\hline $\mathrm{Hi}^{\prime}$ & 300 & 11 & 0 \\
\hline$W i^{\prime}$ & 400 & 0 & () \\
\hline$P^{\prime \prime}$ & 200 & 0 & 0 \\
\hline$H o^{\prime}$ & 360 & 0 & () \\
\hline (ir & 3.30 & 0 & 0 \\
\hline$T / G I^{2}$ & 1.440 & 0 & () \\
\hline$T I G ; I^{2}$ & 960 & () & 0 \\
\hline \multicolumn{4}{|l|}{ Diphtheria } \\
\hline 39 & 250 & 0 & 0 \\
\hline 40 & 405 & 0 & 0 \\
\hline $2 I$ & 560 & 0 & () \\
\hline 131 & 400 & () & 0 \\
\hline
\end{tabular}

' Cord blood specimens.

2 Pooled human tetanus immunoglobulin.

Table 2. Purified antibody preparations (light chain concentrations (micrograms per ml))

\begin{tabular}{|c|c|c|c|}
\hline Patient & $\kappa$ & $\lambda$ & $\lg C$ \\
\hline \multicolumn{4}{|l|}{ Tetanus } \\
\hline$B e$ & $3 \times 0$ & 78 & 500 \\
\hline $\mathrm{Fi}$ & 295 & 6.5 & 300 \\
\hline$w i$ & 370 & 30 & 400 \\
\hline$P e^{\prime}$ & 170 & 25 & 200 \\
\hline Ho & 335 & 40 & 3600 \\
\hline Gir & 325 & 60 & $33(3)$ \\
\hline$T I G ; I I$ & 1350 & $\mathrm{NT}^{1}$ & 1440 \\
\hline TIG $; I I I$ & 1110 & $\mathrm{NT}$ & 960 \\
\hline \multicolumn{4}{|l|}{ Diphtheria } \\
\hline .39 & 225 & 4.5 & 250 \\
\hline 40 & $3+5$ & 90 & 40.5 \\
\hline 21 & +70 & NT & $560)$ \\
\hline 1.31 & 340 & $\mathrm{NT}$ & 400 \\
\hline
\end{tabular}

on three of the tetanus and the four diphtheria samples. For the most part. the quantitations of these allotypic markers approximate the $\lg$ concentrations measured. indicating a predominance of the $\lg \mathrm{G}_{1}$ chain in the purified preparations.

To determine what effect, if any, acid-glycine might have on immunoglobulin content. two specimens of normal sera, brought to a concentration of $\gamma$-globulin approximating that of the antibody preparations. were reacted with the buffer and then dialyzed against normal saline. For comparison, similar dilutions of sera were made with normal saline. The combined results of these studies are shown in Table 5 . All immunoglobulin antigens tested were present after reaction with the buffer, although there was some decline in $\operatorname{Ig} G$ concentration. The $\operatorname{Ig} A$ and $\operatorname{Ig} M$ globulins remained intact after being subjected to buffer, and both $\kappa$ and $\lambda$ light chains (in proper proportions) and all heavy chains were in evidence.

Because of the small quantities of purified material derived. and the number of procedures done with these specimens, antibody nitrogen determination was not attempted. To ensure that all specific antibody was removed from each of the original serum samples, the initial supernatant fluids, after precipitation from sera and the first washes of the precipitate. were tested for either tetanus or diphtheria antibodies. In none could antibody be detected. Further, the purified antibody of patient or was reprecipitated with tetanus antigen to determine whether any nonspecific $\gamma$-globulin was present in the supernatant of the purified preparation. Here. too. none was found. These results indicate that the purification process isolated all specific antibody and did not carry along nonspecific immunoglobulins. 
Table $3 . \lg$ (i allotypes

Patient
Serum (imphenotype

Table 5. (ombrol sera at 1:20) dilution reacted with saline and acid-glycine buffer

$\operatorname{Ig} A . \lg M . \operatorname{Ig}(; . \quad \kappa, \quad \lambda$.

$\mu \mathrm{g} / \mathrm{ml} \mu \mathrm{g} / \mathrm{ml} \mu \mathrm{g} / \mathrm{ml} \mu \mathrm{g} / \mathrm{ml} \mu \mathrm{g} / \mathrm{ml} \lg \left(i_{1}, \lg \left(_{2}, \lg i_{3:} \quad \lg \left(i_{1}\right.\right.\right.$

\begin{tabular}{|c|c|c|c|c|c|c|c|c|c|}
\hline & & \\
\hline Silline & $1(114$ & 75 & 660 & 6.30 & 260 & & & & \\
\hline Butfer & 106 & 69 & +10 & 420 & 2.37 & + & + & + & + \\
\hline \multicolumn{10}{|l|}{ (iN } \\
\hline Saline & 54 & 125 & $5(10$ & $50(0)$ & 228 & & & & \\
\hline Buffer & 50 & 107 & 370 & 3901 & 130 & + & + & t & \\
\hline
\end{tabular}

\section{DISC USSION}

No significance, with regard to antibody selectivity. can be attributed to the expected absence of $\lg A$ and $\lg M$ classes of $\gamma$ globulins in the specimens derived from cord sera or from letanus immune globulin pools. The failure to identify these immunoglobulins in the purified cetanus antibody preparation of the burn patient who received a tetanus toxoid booster is important. Of added significance, in terms of antibody restriction. Was the absence of an $\operatorname{Ig} A$ or $\operatorname{Ig} M$ class of diphtheria antibody in the purified material derived from four patients who had recent clinical discase. These findings are at variance with those of Yount at al. (17). Who describe $\lg A$ and $\operatorname{IgM}$ tetanus and diphtheria antibodies in one adult subject after the administration of tetanus and diphtheria toxoids. Conceivably. some $\operatorname{IgA}$ and $\lg M$ antibodies may have been present in our preparations, but in quantities ton small to be detected by our test systems, $i . e^{\prime}$, in amounts $<5 \mu \mathrm{g} / \mathrm{ml}$. Alternatively. since we were unable of determine precisely whether the times of biond sampling were still within the acute phases of disease. later sampling raises the possibility that $\lg A$ and $\lg M$ antibody production ceased at an carlicr stage.

\begin{tabular}{|c|c|c|c|}
\hline \multicolumn{2}{|c|}{ Purified antibody } & & \\
\hline $\lg \left(i_{1}\right.$ & $\lg (i=$ & $\operatorname{Ig}\left(i_{:}\right.$ & $\lg \left(j_{4}\right.$ \\
\hline+ & - & + & + \\
\hline t & - & + & + \\
\hline+ & - & + & + \\
\hline+ & - & - & - \\
\hline+ & & + & + \\
\hline+ & $\ldots$ & - & - \\
\hline+ & & + & - \\
\hline+ & $\mathrm{NT}^{\prime}$ & $\mathrm{NI}$ & $\mathrm{NI}$ \\
\hline+ & - & - & + \\
\hline+ & - & - & + \\
\hline+ & - & - & + \\
\hline+ & - & - & + \\
\hline
\end{tabular}

In order to be assured that exegenous factors were not responsible for the destruction of IgA and IgM molecules. two specimens of normal sera were incubated with the acid-glycine buffer. as in the separation procedure. No changes in IgA and IgM concentrations were observed. Some decline in IgG concentration was noted following the buffer treatment, but the normal $\kappa: \lambda$ ratio remained unaltered and nome of the heary chain subclasses were eliminated. The fall in $\operatorname{Ig}($ content probably results from aggregation of these molecules (14) and may explain the somewhat lower antibody titers measured in the purified preparations when compared with the titers measured in serum.

Thus. using methods to quantitate immunoglobulin classes and light chains. to describe and quantitate (im factors. and to identify heary chain subclasses we have heen able to demonstrate that there exists partial antibody restriction within the $\lg (i$ class in response to the toxins of tetanus and diphtheria. Although uniform homogencity of antibody could not be established. since some $\lambda$-containing molecules and $\lg B_{3}$ and $\lg B_{1}$ healy chains were variably identified, the quantitative data strongly suggest a $\kappa \lg \left(i_{1}\right.$ predeliction for these antitoxims.

The absence of the $\operatorname{IgC}$, heary chain in all of our specimens is clearly of significance. Although one might argue that $\operatorname{lgG}_{2}$ in cord sera may be relatively scarce $(15)$, others have shown cord sera to possess normal adult proporions of this heavy chain in relation to the other three subclasses ( 8 . 9). Furthermore our other preparations also lacked the $\lg \left(i_{2}\right.$ chain. As $\lg i_{2.2}$ antibody tends to be associated with bacterial capsulat polysaccharides. the failure to find this molecule in any of our samples may relate to the protein nature of the cictanus and diphtheria antigens $(1+)$.

Several reports have described individuals with an inability to produce certain heasy chain molecules. While maintaining the capability to manuficture others (11, 12, 18). Such partial defects often result in an increased susceptibility to infections. The existence of heary chain subclass detetions in the human adds clinical relevance to the recognition of those antigens which clicit restricted antibody responses.

\section{RIFHRHN(TS AND NOTIS}

1. Anderson, B. R. and Terry. W. D): (iammat (i,-glohulin antibody causing inhibition of chotting factor V'lli. Nature. 217: $174(1968)$.

2. Gold. F. R.. and Fudenterg. H. H.: (hromic chloride: A coupling reagent for passive hemagglutination reactions. J. Immunol. 99: $859(1967)$.

3. Kunkel. H. ( $i$.: Individual antigenic specificity. eross specificity and diversity of human antibodies. Fed. Proce. 24: $55(1670)$

4. litwin. S. D). and (amp. F. R. Jr.: Autumated detection of (im taterors of human $\gamma(i$ glohulin. Vux Sang.. 17: 194 11969$)$.

5 Litwin. S. D.: Allotype preference in human Rh ancibodics. I. Immunol.. 110: $717(197,3)$. 
6. Mancini. (;.) (arbonara. A. ().. and Heremans. J. F.: Immunochemical quantitation of antigens by single radial immunodifusion. Immunochemistry. 2: $2.35(1965)$

7. Micracken. (;. H.. Jr.. and Sarff. L.. D.: Current status and therapy of neonatal $t$. coli meningitis. Hesp. Pract. 4: 57 (1974).

§. Mellbye. O. 1.. Natvig. J. B.. and Kuarstein. B.: Presence of Ig(; Subclasses and (1y in human cord sera. Protides Biol. Fluids Proc. Collog. Bruges. 18: $127(1970)$

9. Morell. A.. Skvaril F. van Loghern. F... and klecnola, M.: Human lgG subclasses in maternal and fetal serum. Vox Sang. 21: 481 (1971)

10. Natvig. J. B.. and Kunkel. H. (j.: Human immunoglobulins: (lasses, subclasses. genetic variants and idiotypes. Advan. Immunol. I6: 1 (197.3)

11. Rivat, L.. Ropartz, C.. Burtin. P.. and Cruchaud, A.: Genetic control of deficiencies in $\gamma G$ subclasses observed among families with hypogammatglobulinemia. Nature. 225: 11,36(1970)

12. Schur. P. H.. Borel. H. Gelfand. F W. Alper. ( A. and Rouen. F s Selective $\gamma \mathrm{G}$ globulin deficiencies in patients with recurrent pyogenie infections. N. Fingl. J. Med.. 28.3:0.31 (1970).

13. Steinberg. A. (j.: Progress in the study of genetically determined human gamma globulin types (the Gm and Ins groups). Progr. Ned. (jenct.. 2: I (1962)

14. Tumer. F. W.. and Boyer. P. D.: Interaction of protein antigens and

Copyright c 1977 International Pediatric Research Foundation. Inc antibodics. 111. Disseciatien studies with diphtheria toxoid-antitoxin precipitistes. J. Immunol. 69: $26.5(1952)$.

15. Wang. A. C.. Faulk. W. P.. Stukey. M. A. and Fudenberg. H. H.: (hemical differences of adult. fetal and hypogammaglobulinemia lg( $\mathrm{i}$ immunoglobulins. Immunochemistry. $7: 703$ (1970)

16. Willamsen. A. R.: lsoclectric focusing of immunogiobulins. In: Handhook of Experimental Immunology. Vol. 1. (hapt. 8. 1:d. 2 (Blackwell Scientific Publications, (Oxford. 1973).

17. Yount. W. J.. Dorner. M. M.. Kunkel, H. (;... and Kabat, E. A.: Studies on human antibodies. V'I. Selective variations in subgroup composition and genetic markers. J. Fxp. Med. 127:6.33 (1968).

18. Yount. W. J.. Hong. R.. Seligmann. M. and Kunkel. H. (;.. Structural gene defects and preponderance of $\gamma\left(i_{3}\right.$ subgroup in patients with hypogammatglohulinemiat. J. (lin. Invest. $\$ 8$ : 92a (1969)

19. Diphtheria specimens were kindly given to us by Dr. Wallace Jones of the (enter for Disease (introl in Atlanta. (ieorgiat

20. This work was supported, in part. by research grant NIH USPHS AI 199239.

21. Requests for reprints should be addressed tol: (;. Nathenson. M.D). Department of Pediatrics. Montefiore Henpital and Medical cinter. 111 Last ment of Pediatrics. Montefiote Hospitil
210 th Si.. Bronx. N. Y. 10467 (LiSA).

22. Received for publication November 8 , 1976

23. Accepted for publication April 12, 1977

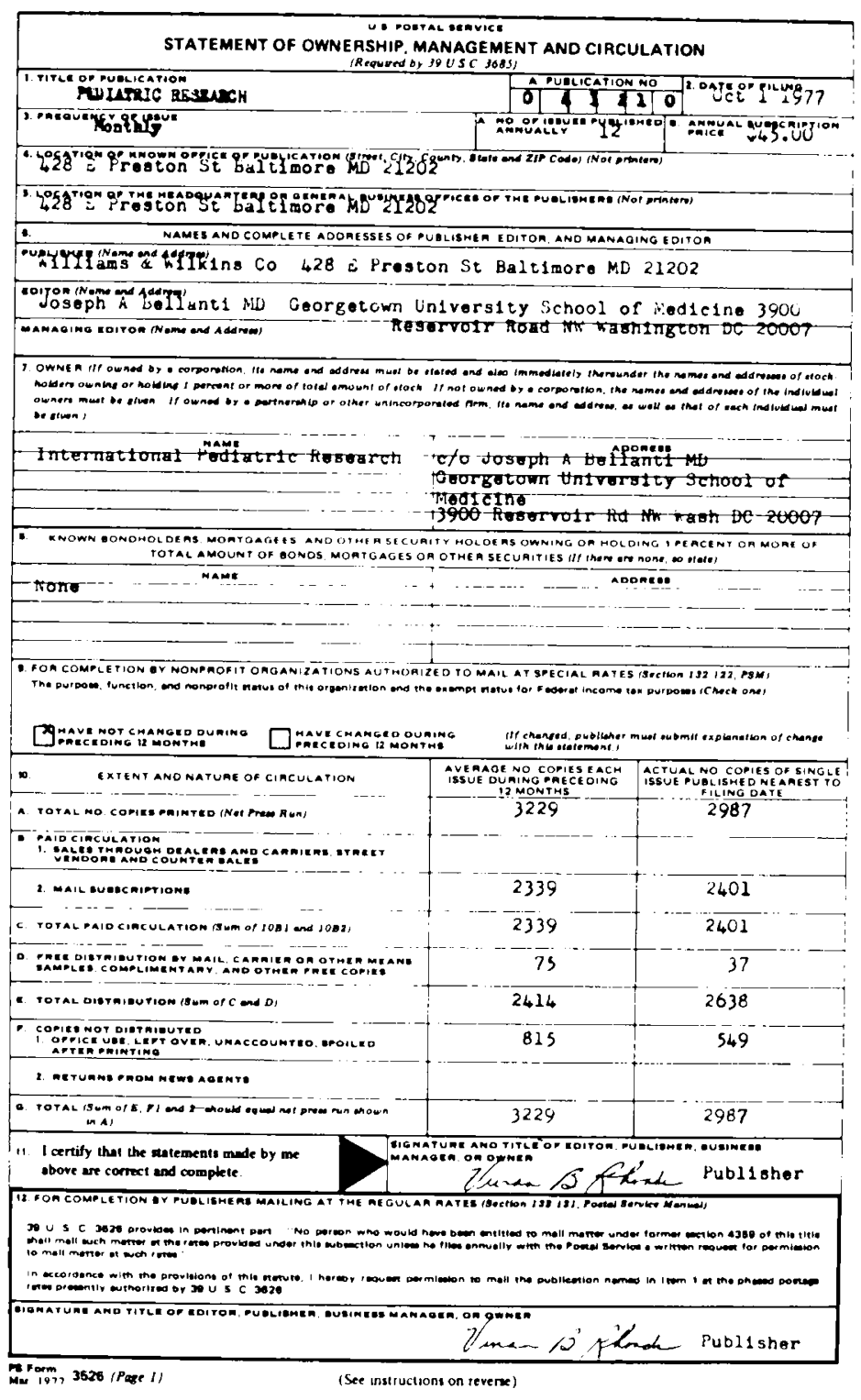

